\title{
Competitive Advantages of Bamboo Creative Products: Study on Saung Angklung Udjo Bandung City West Java Province, Indonesia
}

\section{Encep Sopandi ${ }^{*}$}

Faculty of Social and Political Science, Department of Business Administration Science, Nurtanio University Bandung, Indonesia

"Corresponding author: Encep Sopandi, Faculty of Social and Political Science, Department of Business Administration Science, Nurtanio University Bandung, Indonesia, Tel: +62 22 6034484; E-mail: sopandi07@yahoo.com

Received date: June 20, 2017, Accepted date: September 30, 2017, Published date: October 06, 2017

Copyright: @ 2017 Sopandi E. This is an open-access article distributed under the terms of the Creative Commons Attribution License, which permits unrestricted use, distribution, and reproduction in any medium, provided the original author and source are credited.

\begin{abstract}
This study examines the advantages of local bamboo-based creative products that impact on the economic value and prosperity of the perpetrator the neighborhood community. Focus on the superiority of bamboo instruments with the case Saung Angklung Udjo (SAU), Bandung West Java Province, Indonesia. The qualitative descriptive approach is used, that is conducting in-depth interviews and documentary studies. Primary data are collected from key informants who know the history of SAU's journey since its establishment up to now, consisting of owner, management, staff, craftsmen, players, observers/experts, visitors and stakeholders. Secondary data are collected from documents on SAU, whether from books, journals, reports, newsletters, the Internet and other qualitative data. The objective of the research is to answer the question of how SAU management can focus on bamboo musical instrument business which originally becomes international. The results show that SAU is an effort of traditional culture organization, unique and original region can have competitive advantage so that become cultural value of a nation that can lift image of region and nation of Indonesia besides can give economic impact, giving prosperity for perpetrator and environment of surrounding society.
\end{abstract}

Keywords: Competitive advantage; Entrepreneurial behaviour; Bamboo creative product; Angklung; Traditional Sundanese music; Business performance

\section{Introduction}

The era of creative economy opens opportunities for the creativity of the community to manage the nation's cultural wealth by creating new creations so that existing cultures such as traditional arts have added value and more benefits. Local traditions attract the attention of consumers who want to enjoy what fits a particular culture. "Loved the local culture" means individuals looking for genuine though not necessarily for global brands [1,2]. Creativity in the form of local product development and traditional arts has now become a major force in the global economic turnaround, especially in the service sector, tourism. The successful management of traditional art-based creativity will have a major impact on society, because the creative process is in direct contact with the real problems of society. Such as the problem of cultural preservation, the problem of community welfare, and other socio-economic problems.

The preservation of arts and culture on the basis of local cultural excellence is an interesting model to be developed, in this research is Saung Angklung Udjo (SAU) producing angklung, the original Sundanese local bamboo musical instrument. The reason why bamboo instruments? Bamboo is a natural resource that is familiar in the life of the Sundanese community and the number is quite a lot in the West Java, Indonesia, of 160 species in the world, 150 species exist in West Java. In addition, West Java is very rich in traditional art. It takes effort to multiply, preserve and develop a traditional culture of tradition. The problem in the effort to preserve and develop the local culture is in direct contact with the real problems in the field, namely the problem of the impact on the economic welfare of the community. Thus, the products of local culture and art of tradition are no longer merely art for entertainment or art for art but for the economic welfare of their people. The issue that the existence of local culture and traditional art in Bandung, West Java and Indonesia is weak and faded may be a reality. Some facts on the ground show that many arts and cultures and traditions are not developed, marginalized by popular culture and foreign culture, and even many traditional arts that lack the public's attention, such as puppets from humans, 'Potehi' puppet, art of tambourine, 'Gambang' arts Art of 'Reog', Ludruk art, even for West Java, there are at least 43 traditional arts that are almost extinct.

The phenomenon mentioned above is a classic problem in Indonesia, but not so in the case of Saung Angklung Udjo. The existence of SAU actually shows the facts on the contrary, Udjo managed to pack "Angklung" as a bamboo musical instrument, Sundanese traditional art that until now even exist. The highlight of the creative activity of SAU management is the contribution in delivering "Angklung" as a world cultural heritage belonging to Indonesia which has been approved by UNESCO on November 16, 2010.

This study will examine the competitive advantages of bamboo musical products with the case of SAU, focusing on any activities undertaken by SAU management so that the efforts undertaken in the development of local culture "Angklung" have the advantage to compete and can exist and develop to now. The goal is to know the competitive advantage of SAU in running the business so far. It is hoped that a new model can be found in executing business strategy based on local raw materials and traditional arts to become the best practice for creativity-based business development, with local artistic and cultural products that are unique in each region in Indonesia. 


\section{Literature Review}

\section{Strategy and competitive advantage}

Strategy is a tool for achieving goals. In its development, the concept of strategy continues to grow. This can be demonstrated by the existence of several different strategic concepts for more than three decades. Developments can be seen from the opinions of experts, such as Chandler [3], "strategy is a tool for achieving company goals in relation to long-term goals, follow-up programs, and resource allocation priorities." Learned et al. [4], "Strategy is a tool to create competitive advantage. Thus, one strategic focus is to decide whether the business should exist or not. Strategy is a response, both continuously and adaptively to external opportunities and threats and internal strengths and weaknesses, which can affect the organization [5]. Strategy is a very important tool for achieving competitive advantage. Strategy is an action that is incremental, ever Continuously, based on the point of view of what customers expect in the future. "Thus strategic planning is almost always started from what can happen, not from what happens. The occurrence of new market innovation speed and changes in consumer patterns require core competencies. Companies need to look for core competencies in the business they undertake.

Furthermore, competitive advantage is caused by the choice of strategy by the company to seize market opportunities. There are three strategies that companies can do to gain excellence, namely cost leadership, differentiation and focus. The traditional competitive advantage has been described as a factor or combination of factors that make an organization perform better than any other organization in a competition [6]. It states that better performance of an organization is due to differences in attributes or company factors that enable the company to serve customers better than competitors do, thereby creating better customer value.

It says that no competitive advantage lasts forever. Over time, competitors will also be able to have unique resources, unique capabilities and unique competencies, forming unique ideas and being able to compete with the company [7]. Therefore, competitive advantage can only be maintained with new basic competencies that serve as a competitive advantage in the future. Assert that cost and successful differentiation are built on efficiency, quality, innovation and customer responsiveness.

Barney states that in order to achieve sustainable competitiveness and excellence the company must seek and foster the capabilities of all resources owned [8]. They argue that in the face of increasingly complex competition and internal crises, small firms can use the theory of resources-based strategy. This theory is considered potential to maintain the company's success in the condition of the external environment turbulent, this theory also prioritizes the development of superior internal capabilities, not transparent, difficult to imitate or diverted by competitors and provide a long competitiveness (futuristic) and resistant to recession (recession proof).

The competencies constructed from utilizing the organization's internal assets through continuous organizational learning will produce sustainable capabilities and advantages. Barney [8] states that according to the Resources Base View (RBV) theory, the resources that become sustainable competitive advantage when micro, small and medium enterprises have competencies and resources of value to customers, rare, elusive and difficult to replace, maintaining a good position in the competition on the industry. The RBV approach also states that high business performance will be more easily achieved if the company has competent resources and reliable competitiveness [9]. The coordination of strategic resources resulting from a combination of entrepreneurial orientation and organizational learning will support the creation of non-imitability, non-transferability and nonsubstitutability resources that are sources of sustainable competitive advantage, as stated by Duran [10].

They found empirically that organizational learning has a positive contributor to competitiveness, as well as states that organizational learning is an antecedent of the competitiveness of an organization. In addition to the ability of sustainable competitiveness and organizational learning, factors that are not less important in shaping the success of performance and management of micro, small and medium enterprises is how entrepreneurs can shape the ability of creative and innovative thinking. This creative and innovative thinking process begins with the discovery of ideas that proceed with the ability to form systems of processes, such as ideas, methods and ways of producing unique products and services and generate added value or something new [11]. It states that entrepreneurial success will be achieved if the entrepreneur thinks and does something new or new (thing and doing new things or old thing in new way).

Entrepreneurial behavior is a function of competence. Competence is defined as knowledge, skill and ability that can affect business performance. Furthermore, argued that the failure of entrepreneurs in running micro, small and medium enterprises, among others, due to: incapability in managing management, lack of experience, weak financial control, Lack of strategic management, uncontrolled growth, inappropriate location, lack of inventory control, and inability to make entrepreneurial entrepreneurs Transition).

\section{Bamboo creative product}

Bamboo's creative products are bamboo-based products made from the use of creativity, skills and individual talents to create welfare and employment through the creation and utilization of the creative and creative power of the individual (Ministry of Trade of the Republic of Indonesia, 2008: 4).

Bamboo is one type of grass plants have a variety of benefits. "A clump of bamboo, a million meanings, a million benefits and a million works". Benefits of bamboo include: for raw materials of various industries, construction materials, and biofuels. Utilization of bamboo as industrial raw materials, among others, the manufacture of toothpicks, chopsticks, matches, paper, furniture, various webbing, musical instruments, natural dyes, and food [12]. Creative bamboo products can be made as handicraft materials, either handicrafts that are functional or accessories.

\section{Angklung}

Angklung is a multitonal musical instrument (pitched double) which traditionally developed in Sundanese society in western part of Java Island [13]. This instrument is made of bamboo, sounded by shaking (sound caused by bamboo pipe body collision) to produce a vibrating sound in the tone of 2, 3, to 4 tones in each size, both large and small. In Jonathan Rigg's Dictionary of the Sunda Language, published in Batavia in 1862 it was stated that Angklung is a musical instrument made of bamboo tubes, cut into the edges, resembling pipes in an organ, and tied together in a Frame, vibrated to produce sound. Example of angklung and picture 2 examples of angklung musical instrument games. 
The history and origin of angklung, since when is it? Until now it has not been found, but it is suspected that its primitive form has been used in Neolithic culture that developed in the archipelago until the beginning of modern calendar, so that Angklung is part of preHinduism history in Nusantara-Indonesia culture [13]. Notes about the new angklung appear referring to the time of the Sunda Kingdom (the 12th century to the 16th century).

The creation of angklung is based on the living view of the agrarian Sundanese society with the source of rice life as its staple food. This gave birth to the myth of belief in Nyai Sri Pohaci as the symbol of the life-giving Goddess of Rice (hirup-hurip - sunda, meaning life prosperous life). Dewi Sri offerings by singing songs accompanied by the sound of percussion made of bamboo stems are packaged simple, then born structure of bamboo musical instrument which we know now called angklung.

At first play angklung done at harvest and seren years as part of Sundanese tradition. The angklung music game associated with the rice ceremony becomes a show that is parade or helaran-sunda, even in some places as a procession, coupled with 'Rengkong' and 'Dongdan' art and Jampana (food stretcher). Baduy tribe as the original Sundanese society that still holds the tradition to date, using angklung for the ritual of initiating rice planting.

At the time of the Sunda kingdom, Angklung functioned for the encouragement of war, as a sparking spirit of the people to eliminate the colonization, that is why the Dutch East Indies government had banned the community using angklung, so the popularity of Angklung decline and only played by children at that time. Currently angklung serves as a means of education and entertainment for the people of Indonesia. Angklung managed by SAU has become a medium to establish communication between tribes and nations, becoming a unifying tool of the nation and a means to maintain world peace [14]. The impact is on the increasing popularity of angklung that provides economic and social welfare for the community, not only for the perpetrators but for the surrounding community and also raise the image of the Indonesian nation in the eyes of the world.

\section{Saung Angklung Udjo (SAU)}

SAU is a performance venue, a bamboo handicraft center, and a musical instrument workshop from bamboo. SAU is one of the tourist destinations located at Padasuka Street no. 118 Pasirlayung, CibeunyingKidul Village, Bandung City, West Java Province, Indonesia. SAU was built in 1966 by UdjoNgalagena, better known by calling Mang Udjo with his wife, Uum Sumiati. The goal is to preserve Sundanese traditional art and culture. Udjo was born on March 5, 1929, the sixth son of Wiranta and Imi. Udjo is familiar with angklung art with familiar since the age of 4 years so no wonder if he really loves this art and founded Saung Angklung Udjo.

"... formed on the basis of love and ideals of Mang Udjo Ngalagena (alm) and wife, Mom Uum Sumiati (alm) in 1958 to participate preserving arts typical of West Java region by relying on the spirit of mutual cooperation among fellow villagers, which also aims to Participate in preserving nature and the environment. SAU is an art gallery as a place of art performances, educational and art training laboratories to educate trainers and performers in the field of West Java special art performances, especially angklung music. "

The vision of SAU is to be a region of Sunda culture especially bamboo culture worldwide to realize the leading tourist in Indonesia. Its mission is to preserve and develop the Sundanese culture based on the philosophy of Mang Udjo, namely mutual cooperation between citizens and the preservation of the environment for the welfare of the community. Facilities owned by SAU include: 1) Bale Karesemen, which is a classic style building with sunda roof structure "julang ngapak", theater space for the show in the size of 225meter square with a capacity of 400-500 people. 2) Angklung production center, twostory building area of 300 square meters to the north of Bale Karesemen, where employees produce angklung, from start to convert bamboo bars into angklung that produces the appropriate quality tone. 3) Souvenirs Shop, namely buildings - buildings to display the results of traditional art craft based on bamboo raw materials. SAU receives bamboo handicrafts from bamboo craftsmen of West Java to be marketed, souvenir products, various bamboo crafts and other bamboo artwork. 4). Saung Udjo, which is a saung building to gather together, entertain relations or enjoy susana and culinary typical of sunda'lesehan.' 5) The parking lot can accommodate 4-5 large buses or 10-20 mini buses and 30-40 motorcycles. 6) The back garden, which is the park behind the main building, 1,000 square meters wide with green grass can accommodate up to 150 people. 7) A saree, a garden of more than 1000 square meters, contains cattle like birds and wild birds. 8) Banquet, which consists of 3 areas. First, the guest house area with 10 rooms divided into 2 different clusters. The second area of the Venue, a back garden that can be used for some special occultation. Third, the Food and Beverage area, with a menu of Sundanese cuisine.

\section{Contextual Background and Research Proposition}

\section{Contextual background}

This study will examine the competitive advantage of Saung Angklung Udjo (SAU) in running its business so that it can exist and grow for 50 years more. The approach to problem solving adopts the theory of Man and Chan [10], which is the dynamic nature of competitiveness with the focus of entrepreneurial behavior and behavior through six competencies linked to external factors comprising market heterogeneity, technological shop system, market attractiveness, industrial product Life cycle, market demand and competitive concentration and internal factors, consisting of: innovation, quality, cost-effectiveness and organization. The main objective is the performance of SAU business measured from nonfinancial: customer satisfaction and quality product/service.

Taking into consideration that the frame of mind is built on the indicators outlined above, the frame of mind can be seen [15].

\section{Research proposition}

This research is designed using qualitative research, so it is not derived in the form of hypothesis to be tested, however proposed as follows: "The competitive advantage of bamboo's creative product" SAU is determined by attention to external potential and internal potential Through six entrepreneurial competencies that impact on performance and competitive advantage. "

\section{Research Methodology}

This study used a qualitative approach with case studies on SAU who has been running a business activity for 50 years based on local culture, namely angklung musical instrument. A qualitative approach is a method of exploring and understanding the meanings by which some individuals or groups of people are considered from social problems [16]. Explanation is descriptive, i.e., explaining the results of 
research by presenting a specific picture of the situation, social arrangement or relationship [17]. The research was conducted at SAU, Padasuka street No. 118 Bandung, West Java, Indonesia [18]. The technique of selecting informants was purposive sampling. Primary data were obtained through observation and in-depth interviews of 15 key informants, with owner, management, staff, expert, Sunda traditional observers and visitors as well as stakeholders (government, business, intellectuals and community).

Data needed by the researcher, was collected by using tools, such as: Interview guide, Recorder Tool, Camera (Photo). Processing techniques and data analysis is done by: Organizing Data; Grouping by category, theme and answer pattern, Testing Assumptions or Problems to Data; Finding Alternative Explanations for Data with extension of observation (Triangulation Data) and Forum Group Discussion (FGD); Writing Research Results.

Data from subjects that have been successfully collected are checked again whether they are suitable and appropriate to the research objectives, then whether the conclusions made have been completed $[19,20]$. Writing is a description of data based on in-depth interviews and observations with the subject and significant other. The process begins with the data obtained from the subject and significant other, read repeatedly so that the author understands the problem properly, then analyzed, so that obtained a picture of appreciation of the experience of the subject. Furthermore, the overall interpretation, which in it covers the overall conclusions of the research results.

\section{Results and Discussion}

The description of production management activities SAU, Bandung West Java Indonesia during the year 2015 can be summarized and described as follows; The number of employees involved as many as 71 people, 145 angklung craftsmen, 267 students studio, 216 artists, 1106 production art performances, 92,388 pieces angklung production, the number of visitors as much as 103,952 people. Mutiara Udjo as Operational Manager of SAU said that SAU positioned itself as art studio where art performance and education, culture education laboratory and common space from various community groups that deliver its function as a place that has various values of use, both socially, politically and economically.

Taufik Udjo as President Director of SAU said the stages of travel and business development that have been passed by SAU, he classify the stages within the ten-year period; Phase I (1966-1975) phase 'ngorondang-sunda', meaning born and began to crawl. Phase II (1976-1985) phase of 'lelengkahhalu-sunda', meaning learning to walk. Phase III (1986-1995) phase 'ngawitan tiasa mapah - sunda', meaning starting to walk, Phase IV (1996-2005) phase 'diajar jalan gancang sunda', meaning it can run smoothly. Phase V (2006-2015) the phase of 'jalan gancang-sunda', meaning it starts to walk quickly (2016 forwards) phase 'lumpat-sunda', meaning running, Next phase 'lumpat gancang- sunda', meaning run fast, and 'bisa hiber-sunda', meaning to be able to fly and air. SAU strives to keep alive and thriving, a long life cycle, to our utuk from the management team after the founders left Udjo, we as heirs keep trying to live, and until now more than 50 years running, exist and develop forward . Anang Muftiadi, one of the lecturers of the Department of Business Administration of Padjadjaran University Bandung who is the author of his opinion, stated that consistency, diligence, hard work, and always learning is SAU's strategy in running its business activities so as to gain excellence.

\section{External potential of SAU}

The external environment in the business world can affect the overall business activities undertaken, as well as for the SAU. A summary of interviews with informants regarding the external potential of SAU can be described as follows.

How is the heterogeneity of SAU's market share? Mutiara Udjo explained that over the years, the market segment of SAU has been formed, both for domestic market and overseas market. The demand for angklung products and performances of domestic angklung music arts such as educational institutions, government institutions or business world, as well as foreign market demand is done by government representatives through cultural attaches and foreign businessmen, and many requests from individuals. SAU has often held performances abroad, such as England, France, Singapore, Japan, Netherlands, Germany and others.

What is the quality standard of angklung SAU products? Azis from West Java Provincial Crafts Council stated that the quality of angklung products produced by SAU is good, especially for export quality standards, "I see that SAU management has been trying to meet international quality standards," said Azis. Saung Angklung Udjo has a quality control section to maintain product quality. "Quality standards that we apply not only to the quality of angklung products only, but for other products that enter SAU. We must provide the best for consumers, "said Mutiara Udjo.

How about the state of SAU technology? The technology for making bamboo musical instrument is still simple, does not require high technology, the tools used from the process of bamboo cutting to processing into angklung is still very simple, among others, ax, machetes, saws, which require a tool with computerized technology is a tone matching gauge, So that the resulting tone matches the standard.

How is the attraction of SAU Market? Musical instruments with bamboo material base such as angklung and angklung performances from SAU have its own attraction not only for the domestic community and even the world community. Angklung products from SAU are well known by the markets of various countries. Buyers and visitors of SAU apart from the local communities throughout the territory of Indonesia are also more than 30 foreign countries such as (Netherlands, Germany, England France, Japan, Singapore, Malaysia, China and other countries).

What about the life cycle of SAU industry? Angklung musical instruments and angklung performing arts from SAU, with the age of more than 50 years can be categorized as an art and cultural organization that is quite existing and growing. Referring to the stage, the life cycle in a position is running fast, meaning the stage of maturity. The recognition of UNESCO's international world towards Angklung since 2010 has more to show its existence, in addition to regular daily visits, both from domestic and international, which never deserted. The average daily visitor is more than 100 people.

What about the demand of SAU Market? Market demand for angklung products and angklung music performances is quite high, it is delivered by Mutiara Udjo. "Alhamdulillah from year to year, demand for angklung products and art performances program from SAU always there is an increase."

What about Market competition? All types of businesses will face competition either directly or indirectly. Competitors from angklung Udjo products, are similar products produced by other craftsmen 
Page 5 of 8

outside SAU, even he said today neighboring Malaysia and China, able to make their own angklung. The effort to offset market competition is by continuously developing ideas. Several kinds of ideas developed by SAU among others; a) Creating new ideas in the manufacture of handicraft products that consumers demand, b) Development of handicraft products with modifications so that new models are born to win the competition, $c$ ) Ideas in the manufacture and utilization of the sources of handicraft products, d) Ideas that can prevent boredom Consumers in the use of handicraft products, e) Ideas in the design, model, style, and color of handicraft products favored by consumers, especially creations from the side of angklung performing arts.

\section{Internal potential of SAU}

A description of SAU's internal potential can be summarized as follows: How is SAU Innovation? Innovation conducted by SAU is to create bamboo into angklung whose quality is always improved, then make innovations from the show side, by bringing the visitors to actively play angklung so get special experience, show the visitors that playing angklung music is easy, fun and with a carefree heart happy. In addition, show that Angklung musical instruments, in addition to accompanying traditional Sundanese songs, can also accompany the music or songs from the origin of visitors, such as Western songs or European classical music.

What is the quality of angklung products and performing arts? Referred quality is "the features and total characteristics of a product or service that are attributed to its ability to satisfy the needs of the consumer, both visible and disguised." With regard to the quality of angklung products, SAU applies its quality standards to 3 classifications. Classification 1, very good, 2nd classification, good, and the usual 3rd classification. This is tailored to the target segment and consumer demand. Consumers are given a choice with an explanation of quality standards tailored to the price and needs of consumers. Quality and price in line, meaning the usual quality, harganyapun can be cheaper, medium or high quality, the price was appropriate. But usually it is for certain markets and international markets, SAU always provide goods with the best quality.

What about the cost effectiveness of SAU? SAU has been aware for the cost effectiveness measure, so that the price of the set product has already calculated the cost of production as the determination of the selling price to the consumer. For example, for angklung price unit from the cheapest Rp. 100,000 to the most expensive Rp.500.000/buah or Rp. 1 Million/set to Rp. 5 Million/set (10 units of angklung with various tones). The price already takes into account the cost of materials, wages of employees, and other costs, except shipping charges or freight charges, of course we do not want to lose money in running the business. "Actually for us (me in particular), not only material that becomes a measure of profit, but the inner satisfaction, that bamboo musical instruments, Sundanese traditional art began to be rewarded by the nation itself, especially by the international world."

What about the organization of SAU? The organizing of SAU's business has run the principle of division of labor so that the organization of work or the placement of people and their responsibilities has been implemented. As a result, our organizational and business activities are running to date. "Thanks to god, SAU, from the side of organization and management is getting stronger, so that our existence grows and progresses,"

\section{Entrepreuneur competencies of SAU}

The next description is about the competitive advantage of SAU. In this research is based on the source of superiority of bamboo "angklung" creative products from SAU, which are six entrepreneurial competencies (six entrepreneurial competencies). Entrepreneurial competence is seen as a role in understanding the relationship of activity to the company with the contribution of competitive advantage. Assert that competitiveness is associated with determinants of competitiveness as well as ways in which it can be achieved.

Man and Chan drew research from World Competitiveness Report. It presents three measures of competitiveness, competitive performance, competitive potential and management processes. Emphasis of the dynamic nature of competitiveness by focusing on employer and behavior. A large number of competitiveness literatures is explored by many researchers and identifies six areas of entrepreneurial competence that can enhance competitiveness.

The conceptual model of competitiveness for small businesses, and other authors confirm that six entrepreneurial competencies as a process dimension of competitiveness are combined with external potential that includes competition and internal potential as an organizational capability. The first task of the extension dimension is that entrepreneurs define the scope of corporate competition by examining a number of factors, including: market heterogeneity, technological sophistication, market appeal, product/industry life cycle, market demand and competitive concentration. Second, entrepreneurs focus on internal organizational capabilities, including: innovation, quality, cost effectiveness and organizational (creating flexible organizational structures and systems). Finally, the third task, the entrepreneur sets goals for the company's performance by ensuring that there are effective relationships between the external environment and the company's internal skills. Competitiveness is the way in which entrepreneurs can improve the performance of their companies that can be measured according to a number of dimensions including market shares, profits, growth and duration. Man and Chan [10] stress the importance of competitiveness and performance relationships for long-term orientation rather than short-term. Six entrepreneurial competencies are as follows: Opportunity competencies; Relational competencies, Conceptual competencies, Organizational competencies, Strategic competencies, and Commitment competencies.

What is the competence of opportunity (Opportunity Competencies) SAU? The competence of SAU opportunity as explained by Mutiara Udjo that he always try to exploit every opportunity that exists. "...we have to continue to exist and go forward, market opportunity to develop Angklung musical instrument is very potential, both for foreign market and domestic market, especially after the recognition of Angklung as an instrument of Indonesian original music by UNESCO in 2010." How is the competence of relational competencies (SAU)? SAU establishes relationships with angklung craftsmen outside SAU management, i.e., local craftsmen or artisans outside the region that cooperate with SAU. Interwoven communications woke up very well because according to Mutiara Deciana Udjo "We need each other with crafters, all the musical instrument angklung it is the product of the craftsmen and we do the cooperation."

In addition SAU has built good relational relationships with domestic bamboo farmers and domestic and overseas buyers, so that all orders can be fulfilled. Many of the supports and awards we have 
received, it is evident that we have a good relational relationship with various parties. Evidence that we have good relationship with various parties, among others, the government as a regulator and facilitator in developing regional cultural arts, by providing facilitation to develop various SAU programs especially the facilitation of the Bandung Tourism Office, West Java Province and the center. "... our programs are mostly supported by the government."

Furthermore, the relational relationship of SAU with intellectual or academic is very well established, it is felt in the struggle for angklung to be recognized by UNESCO, Taufik Udjo explained that all this time the intellectuals from various universities in West Java take part in advancing SAU.

SAU's relational relationship with the community, that SAU always maintains relational relationships with various parties, even according to Asep Barnas activist and bamboo craftsman from Tasikmalaya, "... SAU is the center and reference in the development of bamboo art and musical instrument (angklung) of West Java and Indonesia.

SAU established a relationship with the whole community of bamboo lovers, not only for angklung but also all musical instruments made of bamboo and bamboo handicrafts. "We always open ourselves, to anyone," How are conceptual competencies (Conceptual competencies)? That Udjo (alm) has changed the tune of the angklung from diatonic tones to the Pentatonists, has a principle as a Sundanese traditional musical instrument that must be more developed and advanced, anggklung must live and support the perpetrators. Evidently, angklung recognized by UNESCO and increasingly known not only in the country but to foreign countries. Visits of domestic and foreign tourists who come to SAU every day at least 2 buses, 5 mini bus and 10 motor cycle. In terms of information absorption, SAU is very concerned about the absorption and development of information. All information can be viewed through SAU website. How is SAU in terms of risk-taking ability? Management has been trying to make a plan for each program so that at the time of implementation all things are measurable. But if there is anything out of control as part of the risk of running the business, then the management will overcome it by looking at the event, evaluated and taken by management decision Saung Angklung Udjo. The innovation power of SAU continues to be done both from the innovation of angklung raw material procurement as well as from the show program, as has done that is making bamboo garden in cooperation with farmers and making Muri Record in playing angklung musical instrument.

How is Organizational Competence of SAU? Mutiara Udjo stated that SAU has human resources based on expertise possessed based on the criteria required by SAU. The procurement of human resources in SAU has been done based on professional management, "we recruit and locate people according to their needs and expertise," (December 26, 2015). Physical resources owned by SAU is a land of more than 10 thousand square meters located in Padasuka street 118 Pasirlayung Bandung, infrastructure facilities, buildings for production, the stage of the show that accommodates approximately 500 spectators, the marketing area of various handicraft products, ample parking space, Can accommodate more than 5 large buses and 10 mini buses and dozens of two-wheeled vehicles.

SAU's financial resources, "SAU's finances come from family capital, income from business activities and assistance from various parties that are not binding," said Mutiara Udjo.What about the SAU's Commitment Competencies? Udjo (alm.) and SAU management have committed to advance the local musical instrument, and the struggle is continued by their children, so angklung in 2010 has been recognized by the international world as the cultural heritage of the native objects of Indonesia (West Java-Sunda) by UNESCO.

\section{Performance of Saung Angklung Udjo (SAU)}

Company performance in addition can be measured from the financial performance can also be measured or assessed from the side of non-financial. History shows that before 1990, the measurement of company performance can always be seen from the factor of its financial performance, but the latest development of company performance measurement can be seen from non-financial factors. They sponsored a study of future organizational measurements, the results of his study indicate that to measure the performance of managers in the future requires a comprehensive measure that includes four perspectives: from financial, customer, business process, learning and growth perspective. The size that is used as the focus of nonfinancial performance is customer satisfaction (Customer Satisfactions) and product/service quality (Quality Product/Service).

Reveals the strength of nonfinancial performance compared to the standard cost system for control purposes. First, non-financial size performance can be more aligned with company strategy. Management can feel progress and improvement by using non-financial measures to the success of corporate strategy. The second strength is from the actionable side, meaning quick steps in responding to problems. For example, a rapid fall of quality can be responded to, so quicker repair steps are taken to solve the problem. Another example, when the company's low response to a consumer is usually difficult to catch on financial measurement, it becomes easy when the company uses nonfinancial measures. Many of the strengths possessed by measuring performance from non-financial aspects does not mean there are no weaknesses. One of the difficulties of nonfinancial measurement is the inability to the increase that occurred so it is not clear how much profit for the company. For non-financial performance measurement characteristics of bamboo handicraft business, it will be seen from customer satisfaction factor and quality product/service as follows:

\section{Customer satisfactions}

Aspects that can be used as indicators of consumer satisfaction measurement of the product include: product performance, product features, reliability, suitability specifications, durability, easy to repair, aesthetics. Customer satisfactions for angklung and angklung performing arts, Mutiara Udjo and Taufik Udjo as Director and Operational Manager claim that the quality of angklung products they made dare to compete in terms of quality and price with other products. "please prove yourself, that our angklung products are of good quality, because it is done seriously and with heart,".

\section{"We treat our customers very well, the customer is our spirit."}

Through the angklung musical instrument and performing arts, SAU gives awareness to all young people, especially young people in Bandung and West Java Province that bamboo is a very valuable asset that should be made Icon personality of the nation. During this time, consumers who buy angklung Udjo products and become visitors of angklungangklung art feel satisfied and has never been a complain, our communication braid with consumers connected well. More than 5 customers who are interviewed authors represent government institutions, business world, education world, domestic and foreign visitors, they express satisfaction on angklung SAU products, especially unique and unique angklung music performances. 
Page 7 of 8

\section{Quality product/service}

Quality reflects all dimensions of product offerings that generate benefits for consumers. Product/service quality dimensions include: performance of goods/services, durability, conformity with specifications, features, reliability, aesthetics, quality impression, speed and reliability to be repaired Quality Product/Service SAU. A number of consumers, both buyers and visitors SAU interviewed by researchers said that the quality of good and quality angklung, strong endurance, how to play angklung gives its own impression, "we feel involved in angklung music games in SAU, just angklungUdjo music is amazing, we are satisfied Once. "

\section{Findings}

Angklung product and angklung musical performances by SAU by promoting Sundanese special art have an impact on the welfare of the perpetrators and the surrounding community. Saung Angklung Udjo has been able to take advantage of every opportunity available, so nowadays the relation is growing not only the domestic community but also worldwide. The ability of SAU to build relationships and communication is very good, especially with the government, business, educational institutions and others. The prominent competence of Saung Angklung Udjo is the setting to combine business activities, which is not only to sell bamboo musical instruments but to be combined (packed) with artistic cultural performances. SAU has a strong commitment in promoting and fighting for bamboo instruments, especially Sundanese musical instrument "Angklung." SAU's commitment is proven by striving angklung to be recognized internationally as an object's cultural heritage, and UNESCO in 2010 has officially acknowledged that angklung is a typical musical instrument owned by Indonesia. SAU Management has implemented quality standards for various products and events (events) held, so that customers feel satisfied.

\section{Conclusion}

SAU is an institution engaged in creative economy that includes, creative products in the form of angklung made from bamboo raw materials. The uniqueness of SAU's resources is a determining factor of competitive advantage consisting of tangible assets, intangible assets and organizational capability it possesses. Angklung is an asset of art and culture, unique in terms of raw materials, is also unique in its way of being shaken. Another uniqueness of angklung is from the ability to adjust and balance the sounds and tones of modern musical instruments.

The competitive advantage of SAU compared to other art organizations in West Java and Indonesia is a strategy of strengthening the sense of belonging to the "Sundanese" regional culture by living and exercising the nature of the entrepreneurial spirit and optimizing the role and function of quadruple helix which is key in gaining competitive advantage, The existence of SAU until now already more than 50 know still exist even growing rapidly.

Competitors actually are not from art in Bandung or Indonesia alone, but competitors from abroad, where the tendency of Bandung, West Java and Indonesia in general sometimes more appreciate the foreign culture than the local culture itself.

\section{Implications}

Concern that global products and cultures will eliminate local products and cultures has begun to disappear. On the contrary, local products and cultures can thrive by fulfilling the international tradition. Interaction will occur as long as local and global trends find the same or complementary root. This study provides another perspective of competitive advantage, not only in terms of cost effectiveness, differentiation and focus alone. Researchers believe that a typical local factor, traditional can provide something different is supported by the ability to implement entrepreneurial competence into a source of excellence, so that if this is replicated it can also be practiced by other organizations.

\section{Limitation and Future Research}

Research on the competitive advantage of SAU is still limited to the case-specific subject for a local and traditional product-based business organization in Bandung. In addition, the research is not explored by competitors or competition in the same business, due to limited information from similar and parallel similar efforts to become a competitor of SAU. The advantage here is more emphasized on the advantages of being able to run local based business and traditional arts Sundanese angklung in seize the position as a consumer choice, appreciation value of the regular visitors SAU.

Research on the competitive advantage based on local products and local culture as done in the case of SAU is still very limited, therefore further research is needed, not only for the large performing arts organizations but in the art of small and medium performance, With exploratory research based on local raw materials or traditional arts that are found in other areas as a considerable and varied resource in Indonesia.

\section{Acknowledgement}

Authors would like to express his gratitude and highest appreciation to Taufik Hidayat Udjo as President Director and Mutiara Deciana Udjo as Operational Manager of SAU which has allowed researchers to take data. Acceptance and good service for almost a year contribute an adequate knowledge of SAU to researchers.

\section{References}

1. Kasriel-Alexander D (2013) The Top Ten Consumer Tren for 2013.Euro monitor International: News and resources.

2. Arboleda AM, Gonzalez JF (2016) Creating a Competitive Advantage: The Exoticism of Tango nad Salsa From Cali, Colombia. International Journal of Arts Management 19: 42-53.

3. Chandler A (1962) Strategy and Structure. MIT Press, Camridge.

4. Learned EP, Christensen CR, Adrews KR, Guth WD (1965) Business Policy: Text and Cases. Irwin Homewood.

5. Mintzberg H (1994) The Rise and fall of Stategic Planning. Prentice Hall International.

6. Atkinson AA, Waterhouse JH, Wells RB (1997) A stakeholders Approach to strategic performance measurement. Sloan Management Review 38: 25-37.

7. Roger JB (2009) Market-Based Management: Strategies for growing customer value and Profitability. Prentice Hall: New Jersey.

8. Barney J (1991) Firm Resources and Sustained Competititve Advantage. Journal of Management 17: 99-120.

9. Collis DJ, Montgomery CA (2005) Corporate Strategy: A ResourcesBased Approach. Boston: McGraw Hill Companies, Inc. 
Citation: Sopandi E (2017) Competitive Advantages of Bamboo Creative Products: Study on Saung Angklung Udjo Bandung City West Java Province, Indonesia. Bus Eco J 8: 322. doi:10.4172/2151-6219.1000322

Page 8 of 8

10. Man T, Lau T, Chan KF (2002) The competitiveness of Small and Medium enterprises: a conceptualization with focus on entrepreneurial competencies. Journal of Business Venturing 17: 123-142.

11. Covin JG, Covin TJ (1990) Competitive Aggressiveness, Environmental Context, and Small Firm Performance. Entrepreneurship Theory and Practice, pp: 77-89.

12. David WC, Piercy NF (2013) Strategic Marketing. NewYork: McGrawHill.

13. John CW (2010) Research Design: Qualitative, Quantitative and Mixed Methods Approaches. Sage Publications.

14. Pink DH (2005) A Whole New Mind. River head Books-New york.

15. Duane IR, Hoskisson RE, Hitt MA (2009) The Management of Strategy: Concepts and Cases. Ohama: South-Western Cengage Learning.
16. Oswald J, Tilley F (2003) Competitive Advantage in SMEs, Organising for Innovation and Change. John Wiley \& Son.

17. Walker OC, Boydand HW, Lawrenche JC (1999) Marketing Strategy: Planning and implementation. Boston: Irwin/McGrawHill.

18. Walker OCH, Boydand W, Lawrenche JC (2003) Marketing Strategy: A Decision Focus Approach. Boston: Irwin/McGraw Hill.

19. Thomas WL, David HJ (2012) Strategic Management and business policy: Concepts. Pearson Prientice Hall.

20. Amit R, Schoemaker P (1993) Strategic asset and organizational rents. Strategic Management Journal 14: 33-46. 